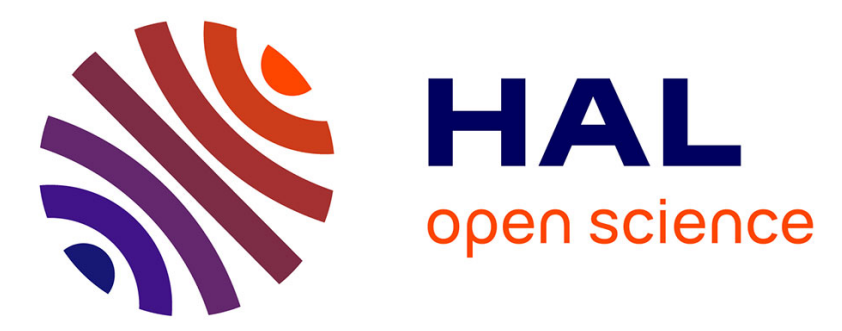

\title{
Pathophysiology and classification of iron overload diseases; update 2018
}

Pierre Brissot, Marie-Bérengère Troadec, Olivier Loréal, Eolia Brissot

\section{To cite this version:}

Pierre Brissot, Marie-Bérengère Troadec, Olivier Loréal, Eolia Brissot. Pathophysiology and classification of iron overload diseases; update 2018. Transfusion Clinique et Biologique, 2019, 26 (1), pp.80-88. 10.1016/j.tracli.2018.08.006 . hal-01880155

\section{HAL Id: hal-01880155}

\section{https://hal-univ-rennes1.archives-ouvertes.fr/hal-01880155}

Submitted on 21 Oct 2021

HAL is a multi-disciplinary open access archive for the deposit and dissemination of scientific research documents, whether they are published or not. The documents may come from teaching and research institutions in France or abroad, or from public or private research centers.
L'archive ouverte pluridisciplinaire HAL, est destinée au dépôt et à la diffusion de documents scientifiques de niveau recherche, publiés ou non, émanant des établissements d'enseignement et de recherche français ou étrangers, des laboratoires publics ou privés.

\section{다)(1) $(5$}

Distributed under a Creative Commons Attribution - NonCommerciall 4.0 International 


\section{TITLE PAGE}

TITLE (anglais). Pathophysiology and Classification of iron overload diseases; update 2018

TITLE (français). Bases physiopathologiques et classification des surcharges en fer ; mise au point 2018

AUTHORS. Pierre BRISSOT ${ }^{(1)}$, Marie-Bérengère TROADEC ${ }^{(2)}$, Olivier LOREAL ${ }^{(1)}$, Eolia BRISSOT ${ }^{(3)}$

\section{AFFILIATIONS}

(1) Institut NuMeCan, Inserm U1241, Université de Rennes 1, Rennes, France

(2) Université de Bretagne Occidentale, Laboratoire de Cytogénétique, CHRU Brest, INSERM UMR 1078 "Génétique, Génomique Fonctionnelle et Biotechnologies", Brest, France

(3) Sorbonne Université, Faculté de médecine, Inserm UMRs-938 centre de recherche SaintAntoine, Service d'Hématologie Clinique et de Thérapie Cellulaire, Hôpital Saint Antoine, APHP, Paris, France

\section{AUTHORS EMAILS}

pierre.brissot@gmail.com

berengere.troadec@gmail.com

olivier.loreal@univ-rennes1.fr

eolia.brissot@gmail.com

\section{CORRESPONDING AUTHORS}

- Brissot Pierre : pierre.brissot@gmail.com

- Brissot Eolia : eolia.brissot@gmail.com

CONGRESS (where this work was presented): Journée SFTS (Société Française de Transfusion Sanguine) - SFVTT (Société Française de Vigilance et de Thérapeutique Transfusionnelle); May 18 2018 ; Paris (France). 


\section{$\because$ ABSTRACT AND KEY-WORDS}

\section{Abstract}

Iron overload pathophysiology has benefited from significant advances in the knowledge of iron metabolism and in molecular genetics. As a consequence, iron overload nosology has been revisited. The hematologist may be confronted to a number of iron overload syndromes, from genetic or acquired origin. Hemochromatoses, mostly but not exclusively related to the HFE gene, correspond to systemic iron overload of genetic origin in whom iron excess is the consequence of hypohepcidinemia, hepcidin being the hormone regulating negatively plasma iron. Iron excess develops following hypersideremia and the formation of non-transferrin-bound-iron which targets preferentially parenchymal cells (hepatocytes). The ferroportin disease has a totally different iron overload mechanism consisting of defective egress of cellular iron into the plasma, iron deposition taking place mostly within the macrophages (spleen). Hereditary aceruloplasminemia is peculiar since systemic iron overload involves the brain. Two main types of acquired iron overload can be seen by the hematologist, one related to dyserythropoiesis (involving hypoferritinemia), the other related to multiple transfusions (thalassemias, myelodysplasia, hematopoietic stem cell transplantation). Congenital sideroblastic anemias, either monosyndromic (anemia) or polysyndromic (anemia plus extra-hematological syndromes), develop both compartimental iron excess within the erythroblast mitochondria, and systemic iron overload (through dyserythropoiesis and/or transfusions).

Résumé

La physiopathologie des surcharges en fer a connu de grandes avancées grâce à une meilleure connaissance du métabolisme du fer et aux apports de la génétique moléculaire. Il s'en est suivi un recadrage nosologique de ces surcharges. L'hématologiste pourra ainsi être confronté à de nombreuses situations d'excès en fer, héréditaire ou acquise. Les hémochromatoses, surtout -mais non exclusivement- liées au gène $H F E$, sont des surcharges en fer d'origine génétique développées du fait d'une hypohepcidinémie, I'hepcidine étant l'hormone régulant négativement le taux plasmatique en fer. Cette hypohepcidinémie génère une hypersidérémie, avec apparition secondaire de fer non lié à la transferrine qui cible préférentiellement les cellules parenchymateuses (hépatocytes). La maladie de la ferroportine présente un mécanisme de surcharge en fer différent puisque associé à un défaut de sortie cellulaire du fer, avec une localisation du fer surtout macrophagique (et donc splénique). L'acéruloplasminémie héréditaire présente la particularité de développer une surcharge en fer systémique incluant le cerveau. Deux grands types de surcharges en fer acquises peuvent concerner plus particulièrement l'hématologiste, la surcharge liée à la dysérythropoïèse et impliquant une hypohepcidinémie, et la surcharge transfusionnelle notamment des thalassémies, myélodysplasies et greffes de cellules souches hématopoïétiques. Les anémies sidéroblastiques congénitales, qu'elles soient « monosyndromiques » (anémie) ou polysyndromiques (anémie en plus d'atteintes extra-hématologiques), ont en commun de développer une surcharge en fer compartimentale mitochondriale érythroblastique, associée à une surcharge systémique (par dysérythropoïèse et/ou transfusions).

\section{KEY-WORDS}

Hepcidin ; ferroportin ; iron overload ; hemochromatosis ; anemia. 


\section{Introduction}

Iron overload, either of genetic or of acquired origin, represents an important field in hematology. Major advances in the knowledge of iron metabolism have provided the pathophysiological bases for revisiting the nosology of iron-related diseases.

1. Reminders on iron metabolism

\subsection{Classical data $(1,2)$}

\subsubsection{Circulating iron}

Considering the hematologist viewpoint, let's start with circulating iron...

\subsubsection{The two forms of blood iron}

Blood iron circulates in two main forms, erythrocyte iron, which accounts for half of the body iron stores (about 1.5-2 g of iron), and plasma iron, quantitatively much smaller than erythrocyte iron and around $5 \mathrm{mg}$ in total.

\subsubsection{The biochemical forms of circulating iron}

Erythrocyte iron is a constituent part of heme which is inserted into four globin molecules, thus forming the hemoglobin macromolecule. Plasma iron, that, as a metal cannot circulate "freely" inside a liquid, is linked to transferrin. Each transferrin molecule can bind at most two iron atoms. Since transferrin is normally present in excess in the plasma, it is found in three potential forms: apotransferrin devoid of iron atoms, mono-ferric transferrin, and di-ferric transferrin. Plasma transferrin saturation corresponds to the number of iron atoms attached to the transferrin molecules. This iron / transferrin ratio is normally less than $45 \%$. Other proteins (hemopexin, haptoglobin and ferritin) can bind plasma iron but are quantitatively minor or negligible molecules in terms of iron transport.

1.1.1.3. The pathways of circulating iron.

While erythrocytic iron is derived from the bone marrow, plasma iron has a dual source (Fig. 1): the absorption of dietary iron through the duodenum and, mostly (quantitatively) the plasma release of splenic iron originating from erythrophagocytosis. The final destination of iron, whether erythrocytic or plasmatic, concerns most cells of the body but, while the bone marrow is the main target of plasma iron, it is the spleen that "receives" the iron from senescent red blood cells. One of the great peculiarities of the iron pathway in the body is its cyclical nature with few new inputs and few losses: in fact, in a very ecological saving design, the iron released by the spleen is taken up by transferrin to regain the bone marrow.

1.1.1.4. Functions of circulating iron

- Erythrocytic iron is used to deliver oxygen to the different cells of the body. Iron is therefore essential for cell life: without iron, the human body could not breathe ...

- Plasma iron, although quantitatively minimal, is qualitatively of major importance. Indeed, this iron participates in a multitude of enzymatic 
reactions (protein and lipid metabolisms, DNA synthesis, biotransformation of xenobiotics ...). Moreover, plasma iron, at the bone marrow level and by its mitochondrial integration (Fig.2), contributes in a crucial way to the synthesis of new red blood cells: it can thus be said that plasma iron is the source of erythrocytic iron and therefore, in cascade, of cellular oxygenation.

1.1.2. Stored iron. The iron which is not used inside the cell is stored within the ferritin macromolecule, a kind of eggshell pierced with pores through which the iron enters it. Thus, ferritin (in its "L-ferritin" form) has a sponge function so as to avoid the toxicity that free iron would exert in the cytosol. Each ferritin macromolecule can store up to 4500 iron atoms. But ferritin also serves as a reservoir by allowing, if necessary, the retained iron to come out through its pores in order to "feed" the cell in situ or to gain the blood flow to reach its transport vehicle, the transferrin. The liver, by the nature of its vascular supply (essentially the portal venous blood coming from both the digestive tract and the spleen) and its cell volume, is particularly effective at taking up and storing circulating iron.

1.1.3. The input-output balance.

One of the major brands of iron metabolism is the quality of its physiological balance. Thus, the amount of dietary iron entering each day ( 1 to $2 \mathrm{mg}$, i.e. one tenth of the iron content of the normal food bolus) is equivalent to the amount that comes out through the digestive, cutaneous or urinary routes. This quantity represents 1 / 2000th to 1 / 4000th of the total amount of body iron.

In all, from these classical data, one can emphasize that, in a very economical and balanced martial system, three proteins exert a determining role: globin as support for erythrocyte heme iron, transferrin for the transport of plasma iron, and ferritin for the storage of cellular iron.

\subsection{Recent data}

They concern iron regulation and toxicity.

\subsubsection{Regulation of iron}

1.2.1.1. A highly finely regulated system

Iron homeostasis derives its regulatory performance from a dual level, cellular and systemic.

- Cellular level. It involves the IRP (Iron Regulatory Protein) / IRE (Iron Responsive Element) system(3). When the iron cell burden decreases, hyperfixation of iron to IRP causes IRP conformational changes which activate its ability to bind to IRE loops of several mRNAs. The blocking of IRE by the IRP, located at the $5^{\prime}$ end of the L-ferritin mRNA, then leads to hypoproduction of this storage protein, which is "logical" in a situation of iron deficiency. Simultaneously, IRP hyperfixation on the $3^{\prime}$ IRE end of the transferrin receptor 1 (TFR1) mRNA blocks the degradation of this mRNA, thus favoring the entry of iron from the plasma into the cell. The action of the IRP is not limited to these two proteins (ferritin, TFR1) : it concerns also, for example, ferroportin (the iron export protein of iron whose activity is decreased in case of iron deficiency ).

- Systemic level (Fig.3). It involves hepcidin, the iron regulating hormone(4-6). Essentially produced by the hepatocytes, hepcidin is a small peptide of 25 amino acids that, once in 
the bloodstream, exerts a double action aiming at the decrease of plasma iron levels. Indeed, hepcidin produces, on the one hand, a decrease in digestive iron absorption, on the other hand a decreased release of splenic iron resulting from erythrophagocytosis. By a mirror mechanism, a decrease in hepcidin hepatic synthesis leads to hypersideremia. This mode of regulation is close to that of the insulin-glucose pair (where hyperinsulinemia leads to hypoglycemia and vice versa), so that one can say that "hepcidin is to iron what insulin is to glucose". This effect of hepcidinemia levels on the rate of sideremia is exerted via another protein, ferroportin, whose hepcidin activates degradation. Knowing that ferroportin is the only membrane protein known to be involved in the cellular egress of iron, any action that hinders its functionality will lead to decreased plasma iron levels. There are two main signaling pathways governing hepcidin synthesis: of course the iron pathway that involves especially the BMP / SMAD system, but also the inflammation pathway that involves the IL6 (interleukin 6) - STAT3 system. To summarize the physiological systemic regulation of iron, the sequence is as follows: a fall in plasma iron levels, a decrease in hepcidin production, and a compensatory increase in iron deficiency (and vice versa).

\subsubsection{Its limits}

Highly efficient, the iron regulation system is also quite vulnerable on two opposite levels: i) The risk of iron deficiency. Indeed, the human body, if it efficiently recycles iron, is not able to synthesize it. It is therefore totally dependent on the intake of food-derived iron ; ii) The risk of iron overload. It comes from the inability of the body to significantly increase iron losses when exposed to an excess of iron intake, whether enteral or parenteral.

\subsubsection{Iron toxicity}

It is considered primarily dependent on non-transferrin bound iron (NTBI)(7). This form of iron is likely to appear in the blood as soon as plasma transferrin saturation rises above $45 \%$. NTBI can be described as a high-speed iron species, with a parenchymal target (Fig.3), which is non-regulatable and potentially damaging. Indeed, NTBI is very avidly captured by parenchymal cells (and primarily by hepatocytes); it is not regulated by the IRP / IRE system so that it continues to accumulate in the cells despite the increase in their intracellular iron load; finally, when transferrin saturation is greater than $75-80 \%$, it exists in a form called LPI (for labile plasma iron) or RPI (for reactive plasma iron). RPI represents the potentially toxic form of circulating iron by its propensity to generate oxygen radical species that can damage not only cell membranes but also intracellular organelles (including mitochondria and nuclei), and DNA(8).

2. Main types of iron overload (Figs.4, 5)

2.1. Iron overload by enteral hyperentry of iron: Iron overload by hypohepcidinemia

2.1.1. Hypohepcidinemia of genetic origin: hemochromatosis (9)

2.1.1.1. Terminology. 
It is now important to reserve the term "hemochromatosis" for iron overload of genetic origin related to hypohepcidinemia. This term should no longer be "backed" by the qualifiers: genetic, hereditary, primitive or idiopathic. As a result, the term "secondary hemochromatosis" should also disappear and be replaced by "acquired iron overload". Similarly, the name, so old and blurred, "hemosiderosis" should no longer be used. In practice, hemochromatoses encompass the following entities: i) hemochromatosis related to mutations of the HFE gene (first and foremost the C282Y mutation in the homozygous state), also known as type 1 hemochromatosis, which is by far the most common form, affecting only Caucasian populations; ii) the so-called juvenile hemochromatoses corresponding to mutations in the hemojuvelin (HJV) gene (type 2A hemochromatosis) or to mutations in the hepcidin gene (HAMP) (type 2B hemochromatosis); iii) hemochromatosis due to mutations in the transferrin receptor 2 (TFR2) gene corresponding to type 3 hemochromatosis, and iv) hemochromatosis by mutations in the ferroportin gene (SLC4OA1) in the rare cases where these mutations lead to a refractory state to hepcidin (and that could therefore be called hemochromatosis type 4, instead of 4B). All these hemochromatoses (types 2, 3 and "4") who are not linked to the HFE gene are rare or exceptional diseases, however not limited to Caucasian populations.

\subsubsection{The common phenotype.}

These different types of hemochromatosis have a common denominator, consisting of the combination of hypersideremia, increased transferrin saturation, and parenchymal type of iron excess (in the first place the hepatocytes). Their clinical picture, very similar, even if strong differences may exist in terms of severity, "speaks" to the clinician who has therefore more facilities for identifying this group of diseases. The hematologist must keep in mind that anemia is not a manifestation of hemochromatosis.

\subsubsection{Iron overload by acquired hypohepcidinemia: Dyserythropoiesis-related iron overload.}

This is a relatively new concept which concerns the hematologist in the first place. Indeed, in the various situations involving dyserythropoiesis, iron overload, with a phenotype identical to that of "hemochromatosis" (as previously defined), can be observed(10, 11). This is the case in thalassemias, either thalassemia major before any transfusion, or thalassemia intermedia (which do not require transfusions). It is also the case in myelodysplastic syndromes which can develop iron overload independently of any transfusions(12). Several medullary factors, generating hypohepcidinemia, seem to be involved in the development of iron overload by dyserythropoiesis, such as GDF15 (growth and differentiation factor 15)(13), TWSG1 (twisted gastrulation modulation factor 1)(14), and the erythroferrone hormone (also called ERFE) $(15,16)$.

Thus, iron overload diseases due to increased duodenal entry of iron are primarily dependent on hypohepcidinemia leading to hyperabsorption of iron contained in normal amounts in the food bowl. As for the role of increased iron content in the diet, it is only accessory because of the physiological saturability of duodenal iron absorption (related to a hyperhepcidinemia reaction)(6), which makes that an iron-rich diet cannot, by itself, cause an hemochromatosis phenotype.

2.2. Iron overload by excessive parenteral entry of iron: Acquired ("iatrogenic") iron overload 
2.2.1.1. Transfusional iron overload(17). It is due to repeated transfusions, each red blood cell unit transfusion introducing into the body about $250 \mathrm{mg}$ of iron, i.e. more than 100 times the daily amount of iron absorbed in a normal subject. Given the inability of the human body to significantly increase its iron output, iron overload develops very rapidly since only 12 red blood cell units transfusion provide the equivalent of the total body iron stores (of the order of $3 \mathrm{~g}$ ). Transfusional iron undergoes the fate of erythrocyte iron, namely the process of erythrophagocytosis, so that its primary cellular destination is the macrophage, therefore essentially the spleen and, to a lesser extent, the liver (at the level of Kupffer cells which are the hepatic macrophages). Transfusional iron overload is therefore initially primarily splenic, in contrast to hypohepcidinemia-related overload where iron excess is essentially hepatocytic totally sparing the spleen (which is "empty" of iron due to activation of macrophage iron export by ferroportin). But, subsequently, the cellular distribution of iron changes. Indeed, because of the gradual release of iron stored in the spleen, plasma transferrin (which receives this splenic iron) saturates, with appearance of NTBI in the plasma. It should be noticed that transfusional iron overload exhibits among the highest NTBI levels, especially as compared with those observed in HFErelated hemochromatosis. Knowing the strong tropism of this iron species for parenchymal cells, iron overload then concerns hepatocytes but also pancreatic and cardiac cells. Transfusional iron overload is therefore primarily splenic but later becomes also strongly hepatic. The concerned diseases are major chronic anemias (thalassemia major, myelodysplastic syndromes, and to a lesser degree sickle cell disease). Special emphasis must be placed on multiple transfusions performed in the context of hematopoietic stem cell transplantation. This type of transfusional Iron overload remains sometimes undetected, being only revealed years later by the finding of marked hyperferritinemia(18).

2.2.2. Iron overload due to excessive supplementation of parenteral iron. Overdose of intravenous ferric hydroxide-sucrose (Venofer ${ }^{\circledR}$ ) or ferric carboxymaltose (Ferinject ${ }^{\circledR}$ ), especially in chronic renal failure with hemodialysis(19), can cause chronic excess iron loading. This type of iron overload concerns above all the macrophagic system but, given the very high levels of hypersideremia observed immediately after the injections, there is a risk of rapid NTBI production, whose cellular target is mainly parenchymal and the action potentially deleterious at the cellular and tissue levels.

\subsection{Iron overload by genetic defect of cellular iron egress: Ferroportin disease}

This form of overload has a pathophysiological basis opposite to genetic or acquired iron overload where there is hyperentry of iron into the cells. Indeed, the mutations of the ferroportin gene (SLC4OA1) in this setting affect the cellular export property of this protein (and not its sensitivity to hepcidin as in the abovementioned case of hemochromatosis "type 4", according to our proposed classification). This results in cellular iron retention. The ferroportin activity being particularly present in macrophages, iron overload is primarily splenic (and moderately hepatic, Kupffer cells being relatively few compared to hepatocytes). As for plasma iron and transferrin saturation, they are not elevated (and may even be low) since iron is only partially released into the bloodstream. In total, the phenotype will be point by point opposite to that of hemochromatosis: nonelevated plasma iron, non-elevated transferrin saturation, and mainly splenic iron excess. In addition, since excess iron is less deleterious when it affects 
macrophages than parenchymal cells, visceral damage is relatively limited(20). In our view, the ferroportin disease should no longer be integrated in the hemochromatosis field given its totally different phenotype, and therefore should not be called type $4 \mathrm{~A}$ hemochromatosis.

\subsection{Iron overload with anemia due to genetic abnormalities of iron metabolism}

Many gene mutations that mark the iron pathway are likely to cause, in addition to iron overload, anemia either by lack of accessibility of plasma iron to the marrow or by deregulation of intramedullary mitochondrial iron metabolism disrupting hemoglobin synthesis. It is therefore a set of iron overload diseases with an overt hematological presentation(21).

2.4.1. Genetic deficiency of the actors of systemic iron metabolism

This deficit is generally observed in rare or exceptional situations.

2.4.1.1. Iron uptake deficiency: mutations of the SLC11A2 gene (solute carrier family 11, number 2) of DMT1 (divalent metal transporter 1) protein. These mutations are responsible for hypochromic microcytic anemia (given the role of DMT1 in the uptake of iron at the apex of duodenal cells) and visceral iron overload (because this protein is also involved in the cytosolic output of endosomal iron) $(22,23)$.

2.4.1.2. Plasma iron transport deficiency: Hereditary atransferrinemia. Due to mutations in the transferrin (TF) gene, this disease associates microcytic anemia (by default of iron transport to the marrow) and iron overload (due to NTBI)(24).

2.4.1.3. Iron endosomal output deficiency: Mutations in the STEAP3 gene (sixtransmembrane epithelial antigen of the prostate family member 3 ). Since this metalloreductase is involved in the step preceding the exit of endosomal iron, mutations in the corresponding gene may cause iron excess, and hypochromic, moderately microcytic, anemia(25).

2.4.1.4. Deficiency of cellular export of iron. Mutations in the ceruloplasmin $(C P)$ gene are responsible for hereditary aceruloplasminemia. The corresponding phenotype associates microcytic anemia with frank hyposideremia and decreased transferrin saturation, contrasting with marked hyperferritinemia. Hyperferritinemia in this disorder reflects systemic iron overload that has the particularity of also affecting the brain (basal ganglia). The mechanism, generally proposed, is the absence of ceruloplasmin-related ferroxidase activity leading, on the one hand, "downstream", to a defect of iron uptake by transferrin (this uptake requiring the oxidation of ferrous iron to ferric iron), and, on the other hand, "upstream", to a failure of cellular iron export function due to subsequent ferroportin dysfunction. However, the absence of splenic overload (theoretically expected in case of ferroportin deficiency) strongly suggests that the mechanistic truth lies at least partially elsewhere $(1,26)$.

2.4.1.5. Anemia and ferroportin disease. Although in the basal state the ferroportin disease is not associated with anemia, anemia may occur during bleeding treatment. Indeed, the default of iron recycling (due to the alteration of iron export function) does not allow, in case of too vigorous bleeding, enough stored iron to be released and reach the marrow for producing compensating red blood cells

2.4.2. Deficit of iron mitochondrial metabolism actors: Congenital sideroblastic anemias (CSAs) (21) 
The common denominator of these conditions is the existence of erythroblastic mitochondrial iron overload, which is at the origin of "ring-sideroblasts", forming in Perls coloration bluish deposits surrounding the nucleus.

2.4.2.1. CSAs in relation to gene abnormalities directly involved in iron metabolism: "Monosyndromic" CSAs.

These CSAs are classically qualified as "non-syndromic". However, inasmuch as they correspond to a real hematological syndrome (the anemic syndrome), it seems preferable to call them "monosyndromic", and to attribute to the affections that include, in addition to the hematological syndrome, extra-hematological syndromes. the qualifier of "polysyndromic". 2.4.2.1.1. X-linked CSA: This disease is related to mutations in the ALAS2 gene (5-aminolevulinate synthetase 2 ). The corresponding protein, ALA synthase, is the first enzyme in the synthetic chain of heme. The phenotype associates hypochromic microcytic anemia and iron overload(27).

2.4.2.1.2. CSA related to SLC25A38 gene mutations. It is, along with the Xlinked CSA, the most common CSA. The protein involved is the erythroid specific mitochondrial carrier protein. The phenotype associates severe microcytic anemia and iron overload, related to both transfusions and dyserythropoiesis(27).

2.4.2.1.3 CSA linked to mutations in the glutaredoxin 5 gene (GLRX5). Glutaredoxin 5 is a mitochondrial protein that is constitutive of iron-sulfur clusters. In case of mutations of the corresponding gene, microcytic anemia with iron excess develops (28).

2.4.2.1.4. CSA linked to mutations in the ferrochelatase gene $(F E C H)$ : erythropoietic protoporphyria. Ferrochelatase is acting at the final stage of the heme synthesis chain. Mutations in the $F E C H$ gene cause mitochondrial overload clinically associated with photosensitivity, liver failure and microcytic anemia. One case of CSA has been reported(29).

2.4.2.2. CSAs in relation to indirect gene abnormalities of iron metabolism: "Polysyndromic" CSAs.

We will just mention CSA associated with ataxia(30), CSA with myopathy and lactic acidosis(31), CSA with pancreas-marrow syndrome (Pearson's syndrome)(32), CSA with immunodeficiency cellular B, periodic fever and developmental delay(33), and thiamine responsive megaloblastic anemia(34). For most polysyndromic CSAs, the question arises of the correlation between genotype and phenotype (35).

2.4.3. The particular case of congenital dyserythropoietic anemias. Although the mutations in question are not related to iron metabolism, the phenotype of congenital dyserythropoietic anemia associates anemia and iron overload, a profile mimicking numerous above-mentioned conditions(36).

In conclusion, the hematologist can be confronted with a multitude of iron overload situations. Genetic systemic iron overload encompasses hemochromatosis (whose 
common pathophysiological denominator for iron overload is hypohepcidinemia), ferroportin disease, and exceptionally hereditary aceruloplasminemia or hereditary atransferrinemia. Acquired iron overload is mainly due to transfusions and dyserythropoiesis. Congenital sideroblastic anemias, characterized by mitochondrial iron overload, are frequently associated with systemic iron overload. The biological diagnosis of these conditions is based (Fig.6) on a first set of blood iron parameters $(37,38)$, followed by genetic testing. While the search for the $C 282 Y$ mutation is easily accessible, the other mutations require expert laboratories.

Acknowledgments. The authors thank for their support INSERM, CNRS, AHO (Association Hémochromatose Ouest), FFAMH (Fédération Française des Associations de Malades de I'Hémochromatose), and AFeMERS (Association Fer-Métaux Essentiels- Recherche-Santé).

Links of interest. The authors declare no links of interest for this article. 
Figure Legends

Figure 1. Iron homeostasis. The two sources of plasma iron are dietary iron absorption and iron recycling from the spleen. Iron osses (digestive, urinary, cutaneous) and intake (digestive) are quantitatively equal, and much lower than recycled iron. Modified from Brissot et al (1).

Figure 2. Fate of plasma iron. Transferrin-bound iron is captured by transferrin receptor1 (TFR1). It enters the endosomes and comes out under the double action of a reductase (STEAP3) and DMT1 (divalent metal transporter 1). According to cellular needs, iron follows, at the mitochondrial level, the pathway of heme synthesis, that of the constitution of iron-sulfur clusters, or that of proteins (notably ferritin).

Figure 3. Dysregulation of iron metabolism during hemochromatosis. Mutations of the HFE, HJV, TFR2 genes, notably by inhibiting the BMP / SMAD signaling pathway, those of the HAMP gene (hepcidin gene), and those (not represented on the scheme) of the SLC4OA1 ferroportin gene (when they alter the sensitivity of ferroportin to hepcidin), lead to a lack of hepcidin hepatic synthesis. The resultant hypohepcidinemia activates the iron export by ferroportin at both the vascular pole of duodenal enterocytes and at the level of macrophages (especially in the spleen). This results in hypersideremia and therefore to an increase in transferrin saturation, which in turn generates the production of non-transferrin bound iron (NTBI). NTBI is avidly taken up by parenchymal cells, primarily the hepatocytes, leading to body iron overload.

Figure 4. Mechanisms underlying the development of iron overloaded anemias related to genetic abnormalities of iron metabolism. Two main mechanisms: i) The lack of iron supply to bone marrow. This defect follows a decrease in plasma iron levels (and thus in transferrin saturation), the origin of which may be mutations of the DMT1 genes, ceruloplasmin, transferrin and, to a lesser degree (essentially in case of too vigorous bleeding regime), ferroportin (when these mutations of the ferroportin gene alter cellular iron export into the plasma); 2) The dysregulation of iron metabolism within the erythroblast mitochondria, as in the case of congenital sideroblastic anemias. Red arrows indicate gene mutations. The genes involved are written in italics. The signs "minus" mean an inhibitory action. Modified from Brissot et al (21).

Figure 5. Pathophysiological classification of iron overload (hematological look). Gene mutations are written in italics. i.v.: intravenous.

Figure 6. Biological diagnosis of iron overload. * see references 37 and 38. 
References

1. Brissot P, Loreal O. Iron metabolism and related genetic diseases: A cleared land, keeping mysteries. J Hepatol. 2016;64(2):505-15.

2. Ganz T. Systemic iron homeostasis. Physiol Rev. 2013;93(4):1721-41.

3. Muckenthaler MU, Galy B, Hentze MW. Systemic iron homeostasis and the iron-responsive element/iron-regulatory protein (IRE/IRP) regulatory network. Annu Rev Nutr. 2008;28:197-213.

4. Pigeon C, llyin G, Courselaud B, Leroyer P, Turlin B, Brissot $P$, et al. A new mouse liver-specific gene, encoding a protein homologous to human antimicrobial peptide hepcidin, is overexpressed during iron overload. J Biol Chem. 2001;276(11):7811-9.

5. Nicolas G, Bennoun M, Devaux I, Beaumont C, Grandchamp B, Kahn A, et al. Lack of hepcidin gene expression and severe tissue iron overload in upstream stimulatory factor 2 (USF2) knockout mice. Proc Natl Acad Sci U S A. 2001;98(15):8780-5.

6. Ganz T. Hepcidin and iron regulation, 10 years later. Blood. 2011;117(17):4425-33.

7. Brissot $P$, Ropert $M$, Le Lan $C$, Loreal $O$. Non-transferrin bound iron: A key role in iron overload and iron toxicity. Biochim Biophys Acta. 2012;1820:403-10.

8. Troadec MB, Loreal O, Brissot P. The interaction of iron and the genome: For better and for worse. Mutat Res. 2017;774:25-32.

9. Brissot P, Pietrangelo A, Adams PC, de Graaff B, McLaren CE, Loreal O. Haemochromatosis. Nat Rev Dis Primers. 2018;4:18016.

10. Camaschella $\mathrm{C}$, Nai A. Ineffective erythropoiesis and regulation of iron status in iron loading anaemias. Br J Haematol. 2016;172(4):512-23.

11. Tanno T, Miller JL. Iron Loading and Overloading due to Ineffective Erythropoiesis. Adv Hematol. 2010;2010:358283.

12. Moukalled NM, El Rassi FA, Temraz SN, Taher AT. Iron overload in patients with myelodysplastic syndromes: An updated overview. Cancer. 2018.

13. Tanno T, Bhanu NV, Oneal PA, Goh SH, Staker P, Lee YT, et al. High levels of GDF15 in thalassemia suppress expression of the iron regulatory protein hepcidin. Nat Med. 2007;13(9):1096101.

14. Tanno T, Porayette P, Sripichai O, Noh SJ, Byrnes C, Bhupatiraju A, et al. Identification of TWSG1 as a second novel erythroid regulator of hepcidin expression in murine and human cells. Blood. 2009;114(1):181-6.

15. Kautz L, Jung G, Valore EV, Rivella S, Nemeth E, Ganz T. Identification of erythroferrone as an erythroid regulator of iron metabolism. Nat Genet. 2014;46(7):678-84.

16. Kautz L, Nemeth E. Molecular liaisons between erythropoiesis and iron metabolism. Blood. 2014;124(4):479-82.

17. Porter JB, Garbowski M. The pathophysiology of transfusional iron overload. Hematology/oncology clinics of North America. 2014;28(4):683-701, vi.

18. Brissot E, Savani BN, Mohty M. Management of high ferritin in long-term survivors after hematopoietic stem cell transplantation. Semin Hematol. 2012;49(1):35-42.

19. Rostoker $\mathrm{G}$. The changing landscape of iron overload disorders at the beginning of the 21st century. Presse Med. 2017;46(12 Pt 2):e269-e71.

20. Le Lan C, Mosser A, Ropert M, Detivaud L, Loustaud-Ratti V, Vital-Durand D, et al. Sex and acquired cofactors determine phenotypes of ferroportin disease. Gastroenterology. 2011;140(4):1199-207 e1-2.

21. Brissot $\mathrm{P} B D$, Brissot $E$, Loréal $\mathrm{O}$, Troadec M.B. Rare anemias due to genetic iron metabolism defects. Mutat Res. 2018(777):52-63. 
22. Bardou-Jacquet $E$, Island $M L$, Jouanolle $A M$, Detivaud L, Fatih $N$, Ropert $M$, et al. A novel N491S mutation in the human SLC11A2 gene impairs protein trafficking and in association with the G212V mutation leads to microcytic anemia and liver iron overload. Blood Cells Mol Dis. 2011;47(4):243-8.

23. Iolascon A, Camaschella C, Pospisilova D, Piscopo C, Tchernia G, Beaumont C. Natural history of recessive inheritance of DMT1 mutations. J Pediatr. 2008;152(1):136-9.

24. Trombini P, Coliva T, Nemeth E, Mariani R, Ganz T, Biondi A, et al. Effects of plasma transfusion on hepcidin production in human congenital hypotransferrinemia. Haematologica. 2007;92(10):1407-10.

25. Grandchamp B, Hetet G, Kannengiesser C, Oudin C, Beaumont C, Rodrigues-Ferreira S, et al. A novel type of congenital hypochromic anemia associated with a nonsense mutation in the STEAP3/TSAP6 gene. Blood. 2011;118(25):6660-6.

26. De Domenico I, Ward DM, di Patti MC, Jeong SY, David S, Musci G, et al. Ferroxidase activity is required for the stability of cell surface ferroportin in cells expressing GPI-ceruloplasmin. EMBO J. 2007;26(12):2823-31.

27. Le Rouzic MA, Fouquet $C$, Leblanc $T$, Touati $M$, Fouyssac F, Vermylen $C$, et al. Non syndromic childhood onset congenital sideroblastic anemia: A report of 13 patients identified with an ALAS2 or SLC25A38 mutation. Blood Cells Mol Dis. 2017;66:11-8.

28. Ye H, Jeong SY, Ghosh MC, Kovtunovych G, Silvestri L, Ortillo D, et al. Glutaredoxin 5 deficiency causes sideroblastic anemia by specifically impairing heme biosynthesis and depleting cytosolic iron in human erythroblasts. J Clin Invest. 2010;120(5):1749-61.

29. Caudill JS, Imran H, Porcher JC, Steensma DP. Congenital sideroblastic anemia associated with germline polymorphisms reducing expression of FECH. Haematologica. 2008;93(10):1582-4.

30. D'Hooghe M, Selleslag D, Mortier G, Van Coster R, Vermeersch P, Billiet J, et al. X-linked sideroblastic anemia and ataxia: a new family with identification of a fourth $A B C B 7$ gene mutation. Eur J Paediatr Neurol. 2012;16(6):730-5.

31. Bykhovskaya $\mathrm{Y}$, Casas K, Mengesha E, Inbal A, Fischel-Ghodsian N. Missense mutation in pseudouridine synthase 1 (PUS1) causes mitochondrial myopathy and sideroblastic anemia (MLASA). Am J Hum Genet. 2004;74(6):1303-8.

32. Sato T, Muroya K, Hanakawa J, Iwano R, Asakura $Y$, Tanaka $Y$, et al. Clinical manifestations and enzymatic activities of mitochondrial respiratory chain complexes in Pearson marrow-pancreas syndrome with 3-methylglutaconic aciduria: a case report and literature review. Eur J Pediatr. 2015;174(12):1593-602.

33. Chakraborty PK, Schmitz-Abe K, Kennedy EK, Mamady H, Naas T, Durie D, et al. Mutations in TRNT1 cause congenital sideroblastic anemia with immunodeficiency, fevers, and developmental delay (SIFD). Blood. 2014;124(18):2867-71.

34. Oishi K, Diaz GA. Thiamine-Responsive Megaloblastic Anemia Syndrome. In: Adam MP, Ardinger HH, Pagon RA, Wallace SE, Bean LJH, Stephens K, et al., editors. GeneReviews((R)). Seattle (WA)1993.

35. Iolascon A. Transfer RNA and syndromic sideroblastic anemia. Blood. 2014;124(18):2763-4.

36. Gambale A, Iolascon A, Andolfo I, Russo R. Diagnosis and management of congenital dyserythropoietic anemias. Expert Rev Hematol. 2016;9(3):283-96.

37. Brissot P. Comment je traite une hyperferritinémie. Hématologie. 2015;21:139-45.

38. Brissot P. BE. Comment j'interprète la saturation de la transferrine. Hématologie. 2017;23:406-12. 


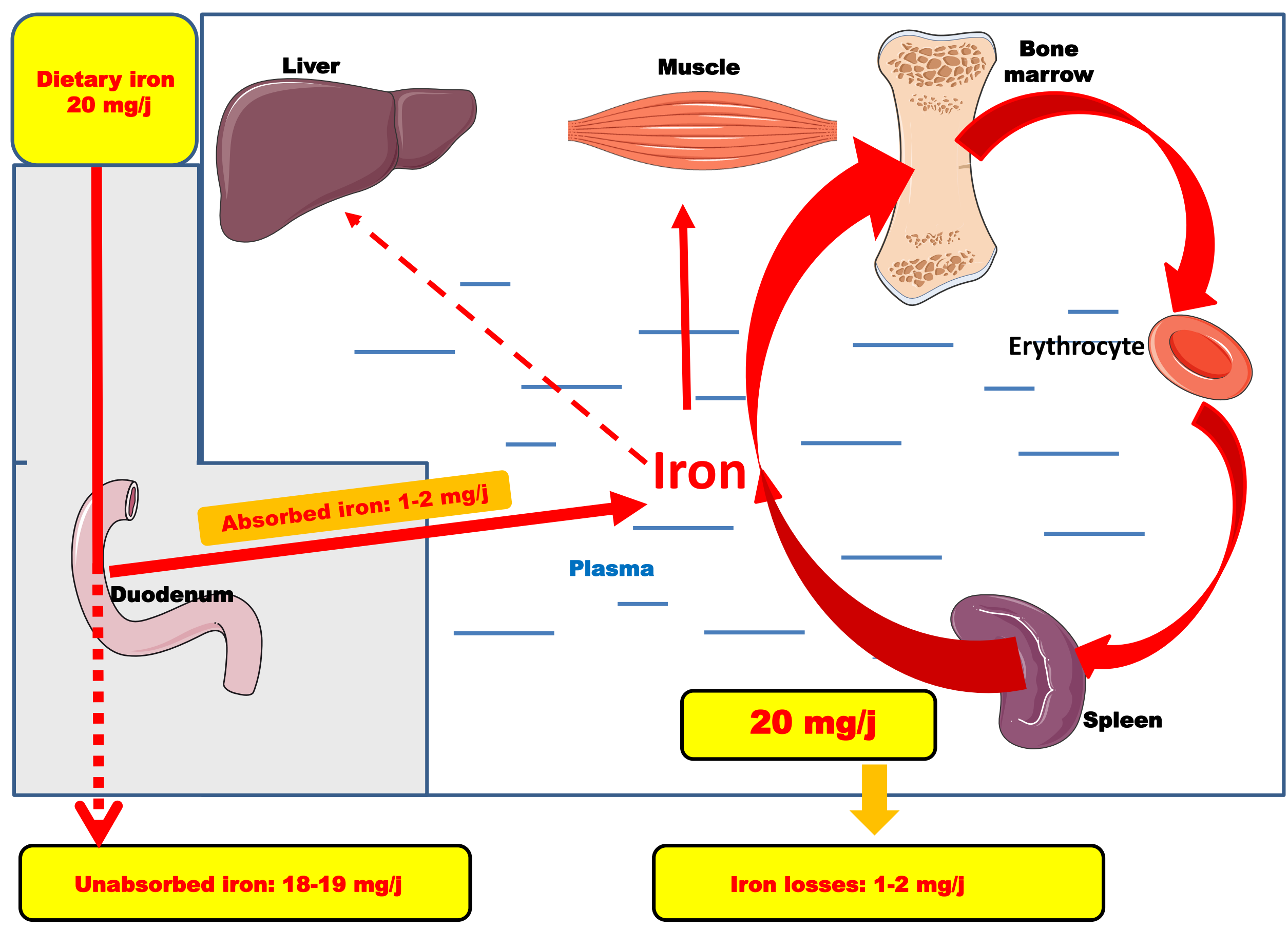




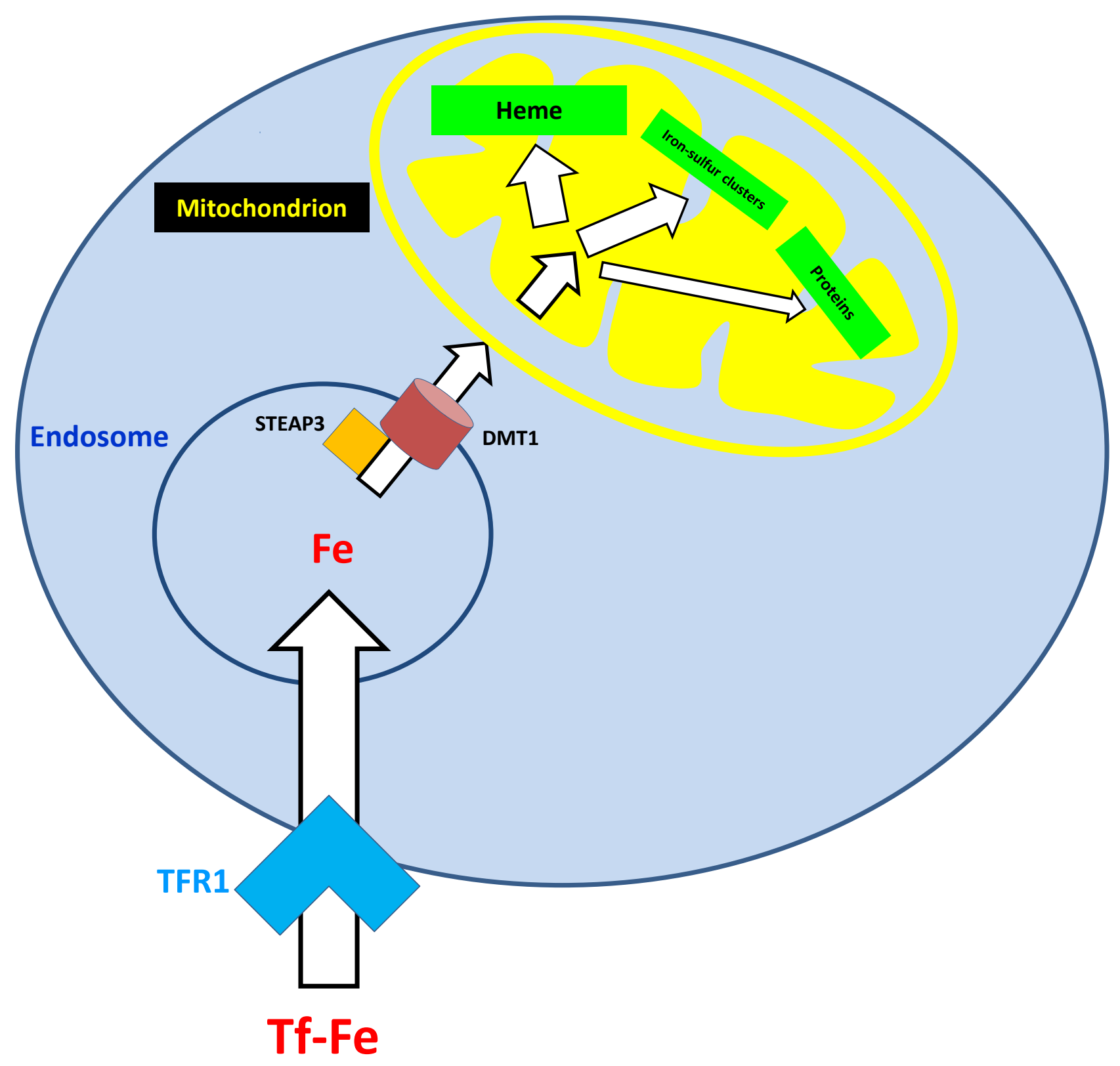




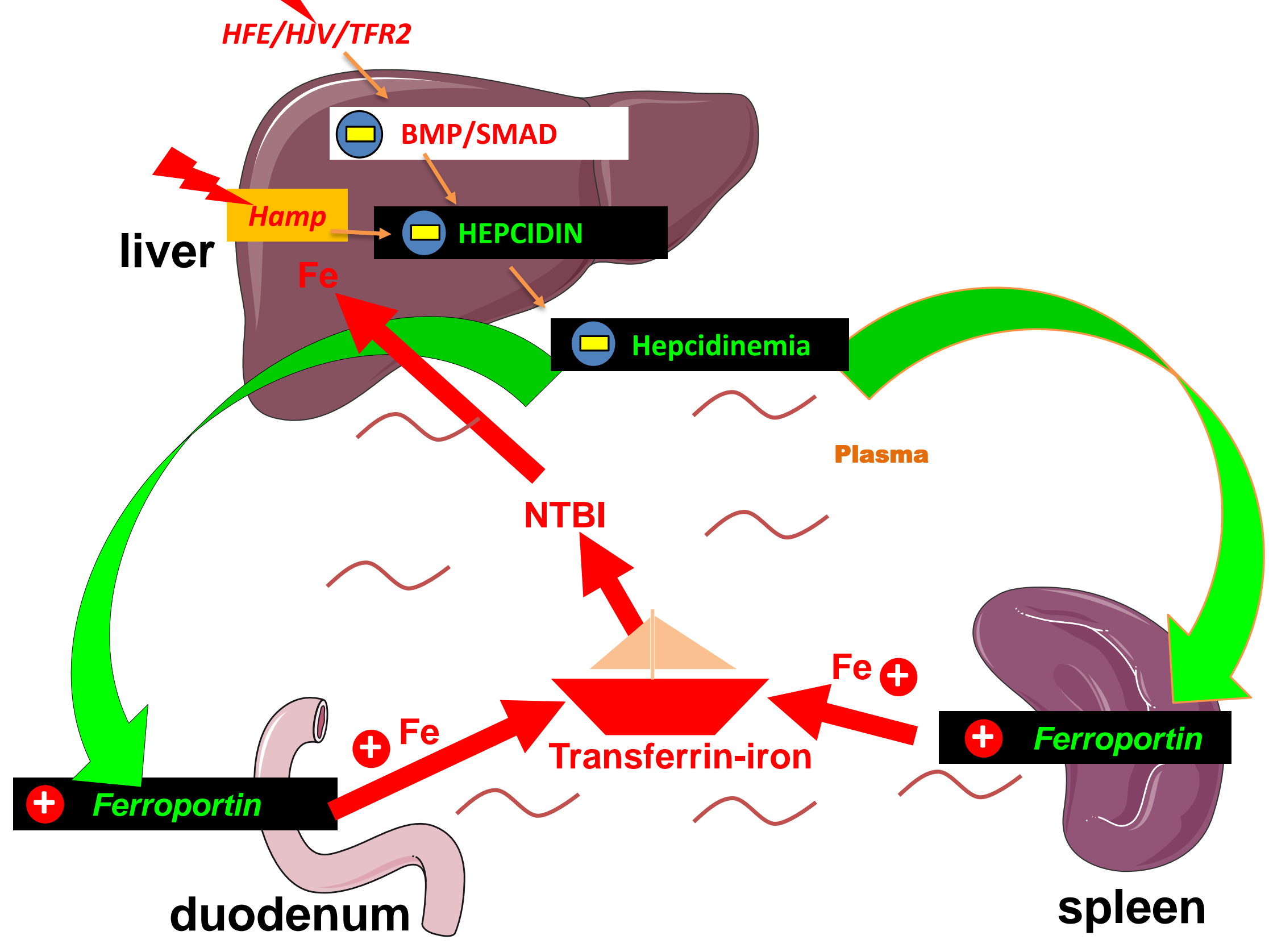




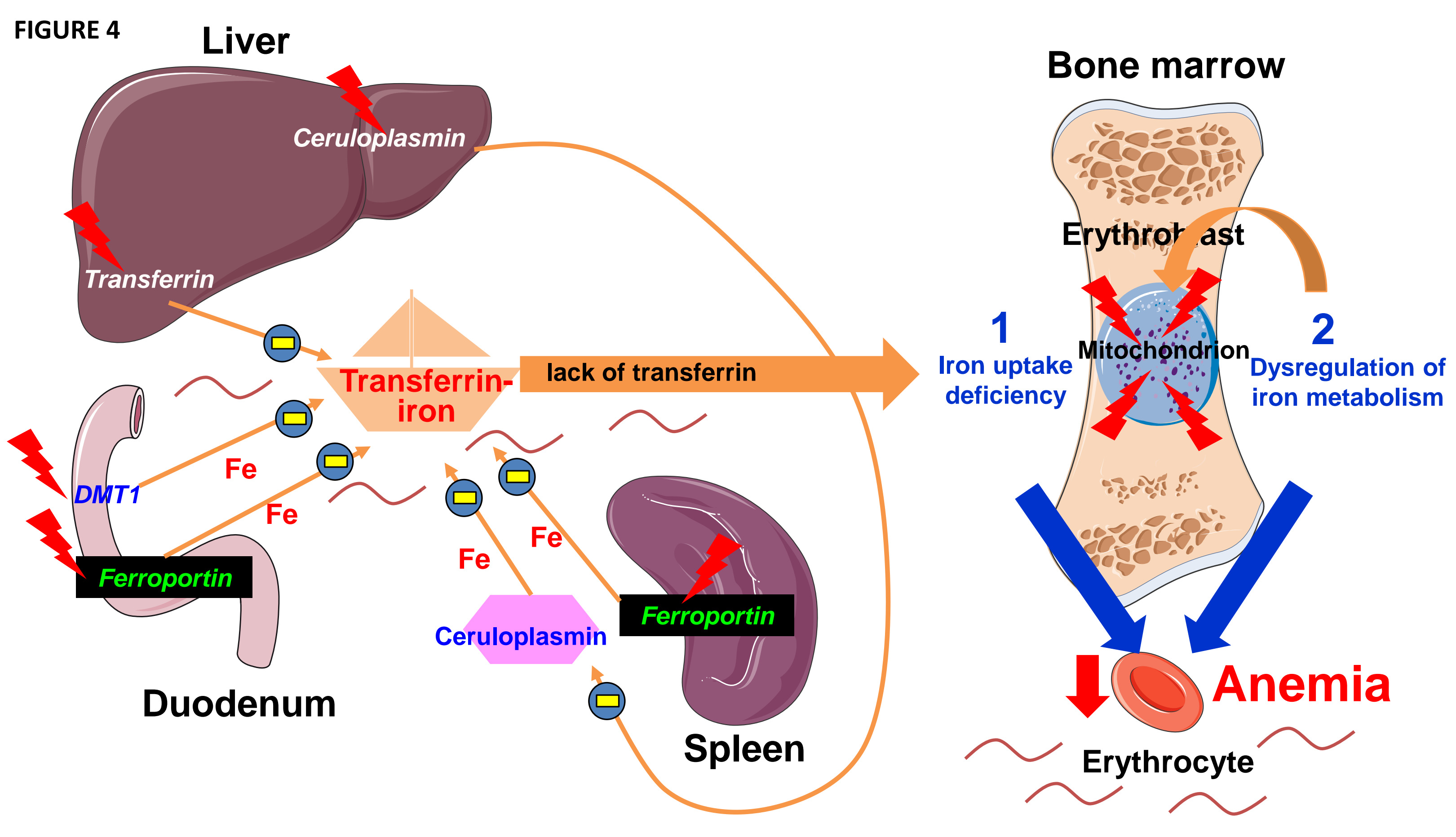




\section{FIGURE 5}

Iron overload

Excessive cellular ingress of iron

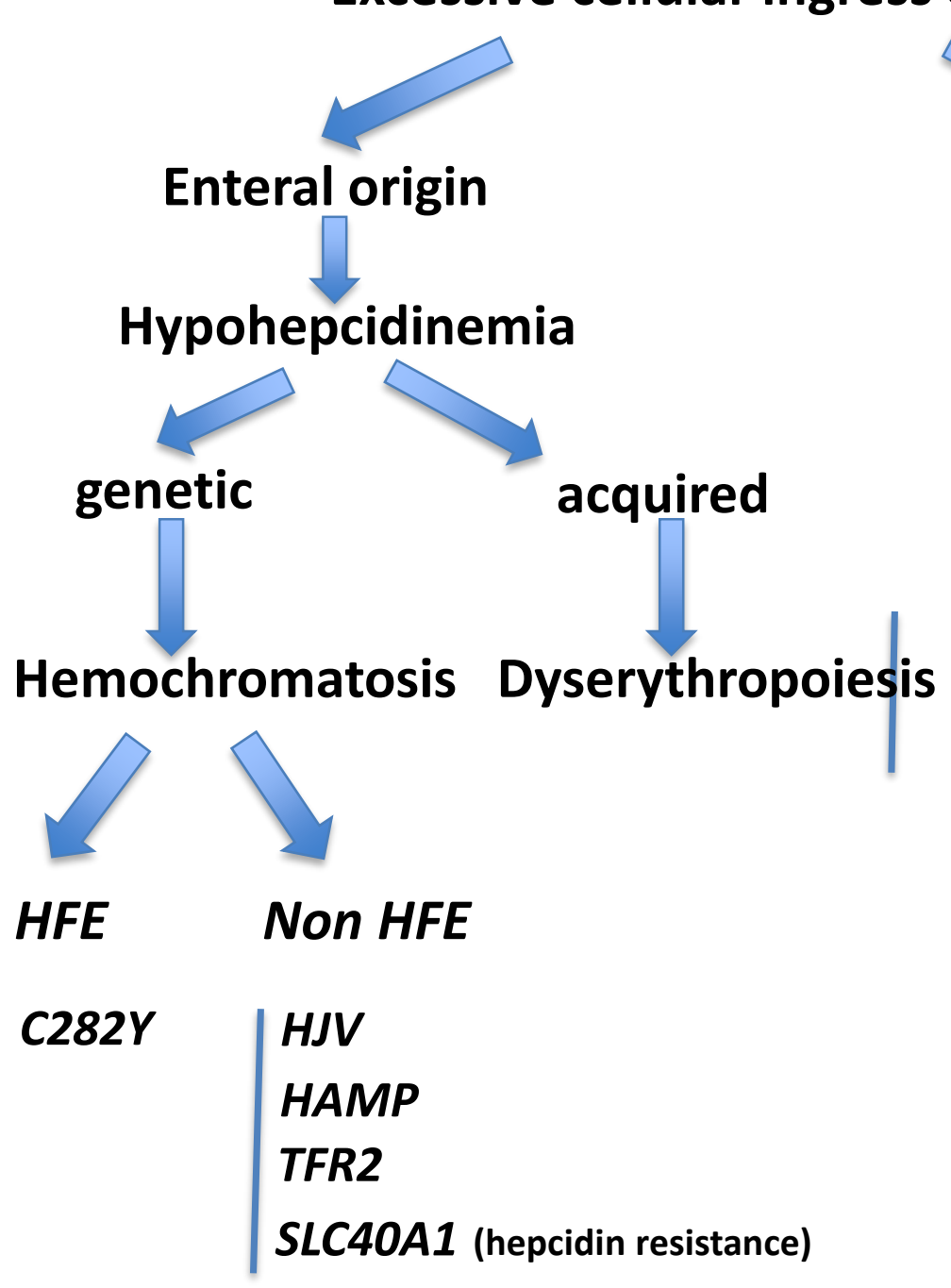

Deficient cellular egress of iron

\section{Parenteral origin}

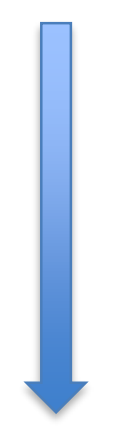

Excessive i.v. iron

Transfusions

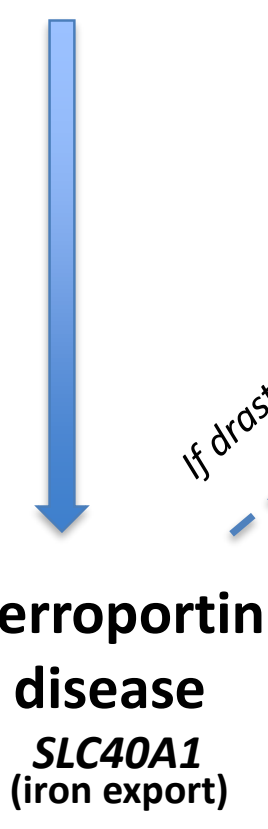

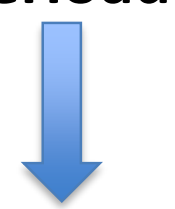

With anemia due to genetic abnormalities of iron metabolism

\section{systemic}

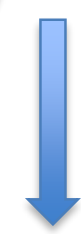

DMT1

Aceruloplasminemia

Atransferrinemia mitochondrial

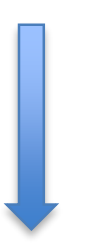

Congenital sideroblastic anemias 


\section{Genetic tests}

. Ferritin*

. C282Y mutation

. Transferrin saturation*

. Other mutations : expert laboratories

. Blood cell count

. Ceruloplasmin 